\title{
Dams and the fish fauna of the Neotropical region: impacts and management related to diversity and fisheries
}

\author{
Agostinho, AA. ${ }^{\mathrm{a} *}$, Pelicice, FM. ${ }^{\mathrm{b}}$ and Gomes, $L C .^{\mathrm{a}}$ \\ ${ }^{a}$ Núcleo de Pesquisas em Limnologia Ictiologia e Aqüicultura - Nupelia, \\ Universidade Estadual de Maringá - UEM, \\ Av. Colombo, 5790, bloco H90, CEP 87020-900, Maringá, PR, Brazil.

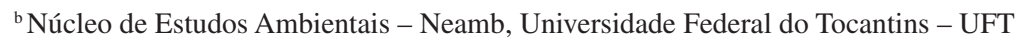 \\ Rua 3, quadra 17, s/n, Setor Jardim dos Ipês, CEP 77500-000, Porto Nacional, TO, Brazil \\ *e-mail: agostinhoaa@nupelia.uem.br \\ Received March 28, 2008 - Accepted March 28, 2008 - Distributed November 30, 2008 \\ (With 6 figures)
}

\begin{abstract}
Reservoirs have been built in almost all of the hydrographic basins of Brazil. Their purposes include water supply for cities, irrigation and mainly, generation of electricity. There are more than 700 large dams and associated reservoirs in the large rivers of the country. These reservoirs favor local and regional economic development, but they also bring serious and irreversible alterations in the natural hydrologic regime of rivers, affecting habitat quality and the dynamics of the biota. In the impounded area, the main impact is the change from lotic to lentic water, which influences aquatic fauna, including fishes. Impacts of reservoirs present relevant spatiotemporal variations. Immediately after reservoir formation, fish species richness usually increases due to incorporation of surrounding habitats, but richness decreases as reservoirs age. However, impacts downstream of dams appear to be similar or stronger than those that occur within the reservoir. Dams promote discharge control, altering the seasonal cycles of floods. These effects are augmented when dams are constructed in cascades. Therefore, dams profoundly influence composition and structure of fish assemblages. Most affected species are the rheophilics and long distance migratory that require distinct habitats to fulfill their life cycles. Populations of migratory species may collapse or even disappear in intensely regulated stretches. Management actions taken to minimize impacts of dams in Brazil historically considered construction of fish passages, fishery control and stocking. The results of these actions are questionable and/or with clear failures. In this paper, we give emphasis to the Paraná River basin, the most affected by dams in Brazil. We describe some patterns in the alteration and decline in fish diversity in areas influenced by dams. We also discuss negative consequences in the fishery and ecosystems functioning. Finally, we argue the relevance and the success of the management actions taken and present some suggestions to improve conservation of the ichthyofauna in South American basins influenced by dams.
\end{abstract}

Keywords: fish diversity, dam impacts, fish management, fish conservation, Paraná River.

\section{Represamentos e a fauna de peixes neotropicais: impactos e manejo relacionados à diversidade e à pesca}

\section{Resumo}

No Brasil, reservatórios foram construídos nas principais bacias hidrográficas, para fins de abastecimento humano, irrigação e, principalmente, geração de energia elétrica. Como resultado, praticamente todos os grandes rios estão hoje sob influência de barragens, sendo que mais de 700 grandes reservatórios encontram-se espalhados pelos rios do País. Apesar de importantes para o desenvolvimento econômico, os barramentos promovem alterações graves e irreversíveis no regime hidrológico natural dos rios, alterando também a qualidade dos hábitats e a dinâmica de toda a biota. Na região do reservatório, o principal impacto é decorrente da alteração de ambiente lótico para lêntico, que influencia sobremaneira a fauna aquática, inclusive peixes. Esses impactos apresentam variações temporais e espaciais relevantes. Logo após a formação de um reservatório, há aumento da riqueza de espécies de peixes devido à incorporação de diversos hábitats, que tende a diminuir à medida que o reservatório envelhece. Porém, os impactos a jusante de reservatórios parecem ser tão ou mais importantes que os de montante, devido a alterações no ciclo de cheias sazonais (controle de vazão). Estes efeitos são mais relevantes quando os reservatórios são construídos em cascatas. Barragens, então, causam profundas alterações na composição e estrutura das assembléias de peixes. As espécies mais afetadas são as reofílicas e aquelas que desempenham longas migrações e que precisam de diferentes tipos de hábitats para 
completar seus ciclos de vida. As populações dessas espécies podem, em certas circunstâncias, entrar em colapso ou mesmo desaparecer. As ações de manejo tomadas para minimizar os impactos das barragens historicamente incluem a construção de mecanismos de transposição e a estocagem, mas com resultados questionáveis e/ou claro insucesso na conservação da ictiofauna. Neste trabalho, será dada ênfase à bacia do alto rio Paraná, a mais afetada por represamentos no Brasil. Serão abordados os padrões de alterações e declínio da diversidade de peixes, em áreas influenciadas por barragens, e discutidas as conseqüências negativas sobre a atividade pesqueira e funcionamento do ecossistema. Por fim, o trabalho discute a relevância e sucesso das medidas de manejo realizadas até o momento e apresenta sugestões para aperfeiçoar a gestão e conservação da ictiofauna sul-americana.

Palavras-chave: diversidade de peixes, impactos de reservatórios, manejo, conservação, rio Paraná.

\section{Introduction}

Fish diversity estimates in Brazilian inland waters are still imprecise due to the lack of complete inventories and the need for taxonomic revision for several groups. New species are described every year, even in those hydrographic basins that are intensely studied. In the Upper Paraná River basin, for example, where there are many ichthyologists working on the most studied fish fauna in South America, there has been an exponential increase in the number of new species described since 1758, when Linnaeus described the first species. This indicates that the number of known species is still underestimated (Langeani et al., 2007). These authors predict that within this decade, the number of new species described will be the highest in history; 36 have already been described since 2000 , and at least 50 more are presently being described.

The number of freshwater fish species in the world is estimated at 13,000. Even considering that a substantial component of the Neotropical fish fauna is still unknown, around 28 to $31 \%$ of the world's diversity can be found in this region (Reis et al., 2003; Lévequé et al., 2008). The Upper Paraná River basin harbors 310 fish species, contributing 7.4 to $8.6 \%$ of the number estimated for the Neotropical region; this diversity far exceeds that presumed by Bonetto (1986) more than 20 years ago (130 species). For example, intensive surveys conducted in the remaining area of the Upper Paraná River floodplain $(526,000$ ha; $0.4 \%$ of the Atlantic Forest biome, to which it belongs), found 182 fish species (Graça and Pavanelli, 2007), representing more than $50 \%$ of the total diversity found in the basin and in the biome (Agostinho et al., 2005).

In spite of the high fish diversity that characterizes the Upper Paraná, there have been marked changes in patterns in fish distribution and community structure, and the fish fauna is under serious threat. The Paraná River basin in Brazil has the highest human occupation in the country (32\% of the population in just $10.5 \%$ of Brazilian territory). The largest urban and industrial centers in South America are located within this basin, and these areas have severe impacts on the amount and quality of the water returning to the river (Agostinho et al., 1994). For example, the sub-basin of the Tietê River $\left(72,000 \mathrm{~km}^{2}\right)$, is where almost half the population of the basin lives, and more than $95 \%$ live in urban

centers. During the dry season, some river tributaries have nearly $2 / 3$ of their discharge composed of sewage (Petrere and Agostinho, 1993). In addition to the increasing demand for water, consumptive uses, intense agriculture and cattle-raising activities (mainly with inadequate soil management), intense use of agricultural chemical agents, and elimination of riparian vegetation, species introductions have degraded water quality in the main tributaries of the upper Paraná River. As a consequence, the water of this basin is becoming ill-suited for human use, and the support of aquatic life is limited. Cascades of dams have contributed to improving water quality in the basin. Between the sources of the Tietê River and the floodplain of the Paraná River, for example, there are eight large dams that aid in purification and retain pollutants. Improved water quality has been noted below the first series of dams (Agostinho et al., 1994). However, dams are among the most damaging human activities in the basin, and these have deeply modified the physiography of watersheds in the region. They have affected virtually all main river courses, especially those in the upper half of the Paraná River.

An unavoidable effect of impoundments is the shift in fish species composition and abundance; this includes the extreme proliferation of some populations and a reduction, or even elimination, of others. The intensity of these impacts is greatly influenced by characteristics of the biota and of the reservoir itself (Agostinho et al., 1999, Araujo and Santos, 2001), the presence of other reservoirs in the basin, and dam design and operation. The identification of the sources of impact is not an easy task, mainly because they arise from plenty of complex interactions, different watershed uses, and geology. In this case, the conservation of fish fauna demands a thorough scientific understanding of the system to be successful. In recent decades, the main activities related to fishery and fish diversity management in Brazilian reservoirs (fishery regulation, stocking and fish ladders) were, in general, unsuccessful or even caused greater impacts (Agostinho et al., 2004d; Agostinho et al., 2007b).

In this paper, we review the more conspicuous impacts caused by impoundments on Brazilian fish diversity, and we discuss how management actions have been conducted to mitigate impacts and conserve the fish fauna. The data used are mainly from the upper Paraná 
River basin because it is the most studied (and most impounded) basin in the Neotropical region.

\section{The Upper Paraná River Basin}

The Paraná River is the second longest river in South America $(4,695 \mathrm{~km})$, the tenth largest river in the world for water discharge and the fourth in drainage area $\left(2.8 \times 10^{6} \mathrm{~km}^{2}\right)$. The Paraná basin is formed by the Paraná and Paraguay rivers, which occupy most of the Central-South part of South America $\left(18^{\circ}\right.$ to $34^{\circ} \mathrm{S}$ and $45^{\circ}$ to $68^{\circ} \mathrm{W}$ ) from the Andes to the Serra do Mar near the Atlantic Ocean (Agostinho et al., 2007a)

The Upper Paraná River includes approximately the first third of the Paraná River basin, and it lies completely within Brazilian territory, except for one stretch along the Itaipu Reservoir that borders Paraguay. The Upper Paraná River has a drainage area of $891,000 \mathrm{~km}^{2}$, or $10.5 \%$ of the total area of Brazil. It flows south-southwest through the region of the greatest population density in Brazil. Its climate is tropical/sub-tropical, with an average annual temperature of $15^{\circ} \mathrm{C}$ and more than $150 \mathrm{~cm}$ of precipitation each year (IBGE, 1990).

The rivers that form the Paraná River are similar to other plateau rivers, with an average slope of $0.8 \mathrm{~m}$ per $\mathrm{km}$, decreasing in the middle portion to $0.3 \mathrm{~m}$ per $\mathrm{km}$. Before the closure of the Porto Primavera Dam (closed in 1998), a large floodplain existed from Três Lagoas (MS) to Guaíra (PR), extending for c.a. $480 \mathrm{~km}$. Currently, this floodplain includes a stretch of $230 \mathrm{~km}$ from the Porto Primavera Dam to the upper part of the Itaipu Reservoir (slope $0.18 \mathrm{~m}$ per $\mathrm{km}$ ). This floodplain, especially on the western margin of the Paraná, may be up to $20 \mathrm{~km}$ wide. In this area, the Paraná River is braided with an accumulation of sediments in its channel forming sandbars and small islands and a few large islands. The complex anastomosis in this stretch involves secondary channels, the Baia River and lower parts of tributaries on the western margin (Ivinheima, Amambai, and Iguatemi rivers) of the basin.

The first large reservoir in the Upper Paraná River basin was the Parnahyba hydropower reservoir $\left(3.5 \mathrm{~km}^{2}\right.$ surface area; $34 \mathrm{~m}$ high), which was closed in 1901. This reservoir is now named Usina Elevatória de Edgard Souza. More than 145 large dams have now been constructed; $70 \%$ are used for hydroelectricity, and they inundate 16,700 km² (Agostinho et al., 2007b). This area corresponds to almost $50 \%$ of the total area impounded in Brazil, which supplies around $70 \%$ of the electricity consumed. Most large tributaries (Paranaiba, Grande, Tietê, Paranapanema), and even the main channel of the Paraná River, have been transformed into a cascade of reservoirs (Figure 1). The last relevant stretch of running water in the Paraná River is restricted to $230 \mathrm{~km}$ between the Porto Primavera Dam and the Itaipu Reservoir; it is protected by three conservation units (Protected Área of the Ilhas e Várzeas do Rio Paraná, National Park of Ilha Grande, and the State Park of Ivinheima).

\section{Impacts Caused by Dams}

River damming is a process so intense and dramatic that it results in the creation of a new ecosystem (Baxter, 1977), with a particular structure, biota and functioning. Therefore, the occurrence of environmental impacts is inherent with any impoundment, a process fundamentally linked to the control of river flow. Though describing a single hydrological attribute, water flow represents the main force behind freshwater ecosystems, and it is responsible for their geological/hydrological structure, productive dynamics (matter and energy), nutrient cycling and the distribution and evolution of the biota (Poff et al., 1997). As a consequence, the loss of natural flow regimes has far-reaching impacts, including alterations in pristine hydrological dynamics, historical patterns of biological production, distribution of biodiversity in space and time, and changes in functions and services provided by aquatic ecosystems (Nilsson et al., 2005).

Even though several modifications usually follow the construction of any dam, Petts (1984) recognized some order to the temporal succession of impacts: i) first order impacts, which include physical, chemical, geomorphological and hydrological modifications, as a consequence of spatial/temporal redistribution of river flow; ii) second order impacts, which involve modifications in the structure and dynamics of primary producers, in addition to geological alterations in the river channel; and iii) third order impacts, which involve major modifications in the community of consumers, especially invertebrates and fish as a result of modifications in flow, producer dynamics and habitat fragmentation. After river damming, the new system develops (through succession) and may even reach a period of greater stability or of lower functional variability, but the occurrence of new disturbances - a common feature in impoundments - may interrupt successional dynamics. Therefore, other factors may influence or promote alterations in the impounded environment, such as dam operations, the introduction of non-native species, watershed occupation (agricultural, industrial and urban), construction of new impoundments or even the removal of dams.

Because this topic is extensive and has been discussed elsewhere (Petrere Jr., 1996; Poff et al., 1997; Agostinho et al., 1999; WCD, 2000; Nilsson et al., 2005; Agostinho et al., 2007b), here, we present a brief synthesis of the main impacts that have been observed for the fish fauna in the impounded areas of South America. More emphasis has been given to the reservoir area, maybe due to the impressive landscape alterations that have occurred in upstream stretches and the obvious influence on aquatic and human populations. However, serious impacts, often those much more harmful, have been reported in downstream environments; these are areas historically considered less often by environmental studies.

\subsection{Impacts upstream from the dam}

The upper Paraná River basin, as well other large South American basins, has had its physiography deep- 
ly altered by hundreds of large dams. To some extent, landscapes are dominated by immense water bodies with lentic or semi-lentic characteristics (reservoirs), which differ from natural lakes with respect to hydrological, limnological and ecological dynamics (Tundisi and Matsumura-Tundisi, 2003). Depending on the shape and area of the reservoir, a longitudinal hydrological gradient may develop from the dam (lentic zone) to upstream reaches (riverine zone), showing intermediate characteristics in middle stretches (transition zone, with lentic and lotic features) (Kimmel et al., 1990). These gradients have relationships with the intensity of impacts, with limnological characteristics and dynamics, and with the biota that occupies each different zone, as in the case of the Itaipu Reservoir (Agostinho et al., 1999, Oliveira et al., 2004; Okada et al., 2005; Figure 2).

The reservoir undergoes fast and intense modifications after it is filled because a lotic ecosystem is suddenly transformed into a lentic or semi-lentic environment. The new ecosystem is colonized by those species that inhabited the original river, and the established com- munity will depend on the nature of the fish fauna (e.g., presence of sedentary or migratory species) and on the intensity of first and second order impacts (Castro, 1997; Alves et al., 1998; Agostinho et al., 1999). Local species richness ( $\alpha$ diversity) usually increases during the first months after filling due to the mixture of local assemblages formerly distributed over a range of fluvial environments, now flooded and homogenized. During this time, fish show intense activity and may use the entire water column (Agostinho et al., 2007b), possibly stimulated by the lack of familiarity with the new and extensive environment (e.g. pelagic area).

Soon after the reservoir is filled, patterns of thermal/ chemical stratification intensify progressively in the water column, along with the decay of the flooded organic matter (vegetation, litter and soil). Consequently, environmental quality may deteriorate in some layers of the column (e.g., thermal stress, low dissolved oxygen, acidification), especially close to the bottom (Matsumura-Tundisi et al., 1991; De Fillipo et al., 1997; Thomaz et al., 2001). These new dynamics have direct

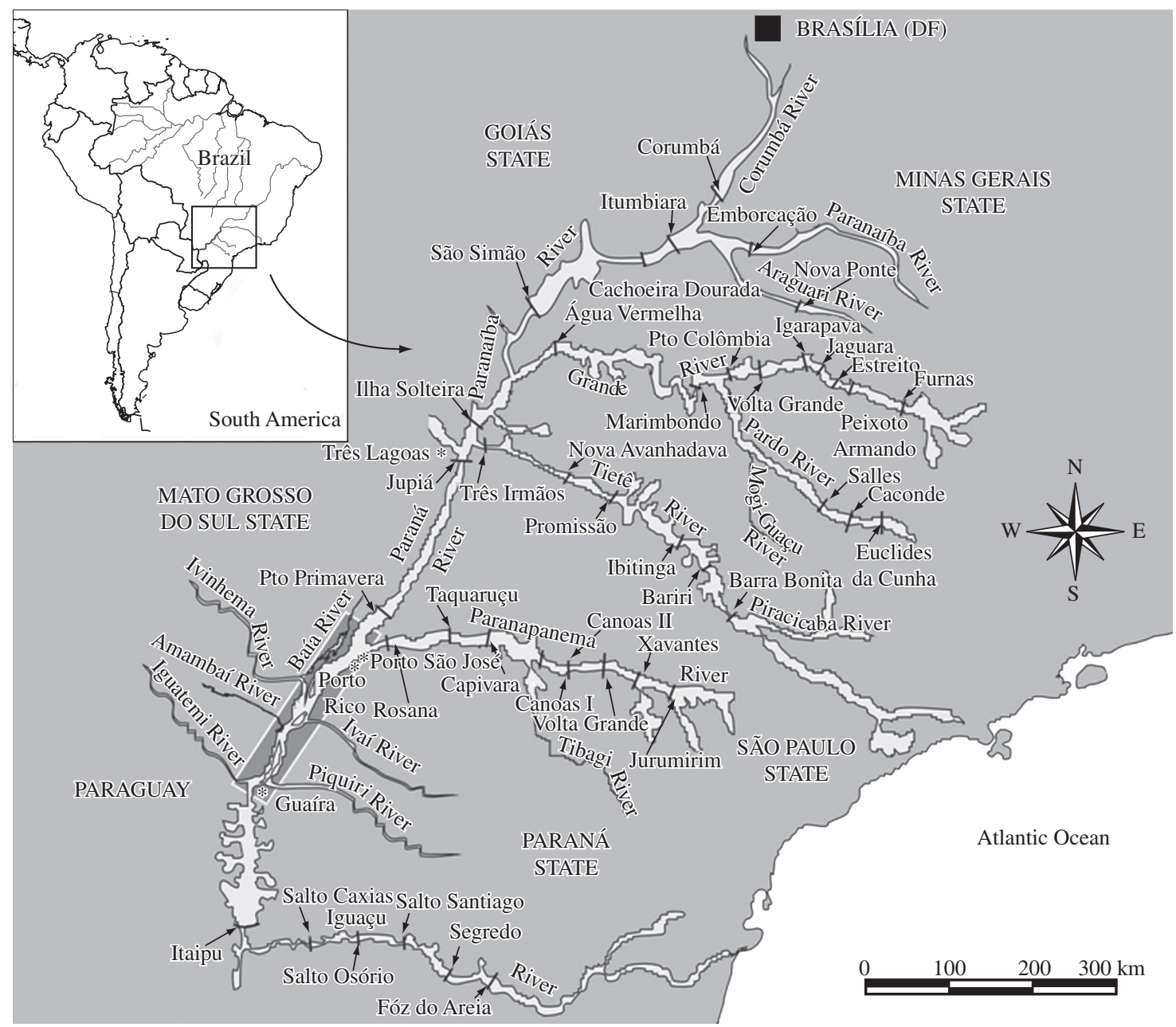

Figure 1. Main Brazilian reservoirs in the Paraná River basin. The rectangular box shows the remaining floodplain stretch. 


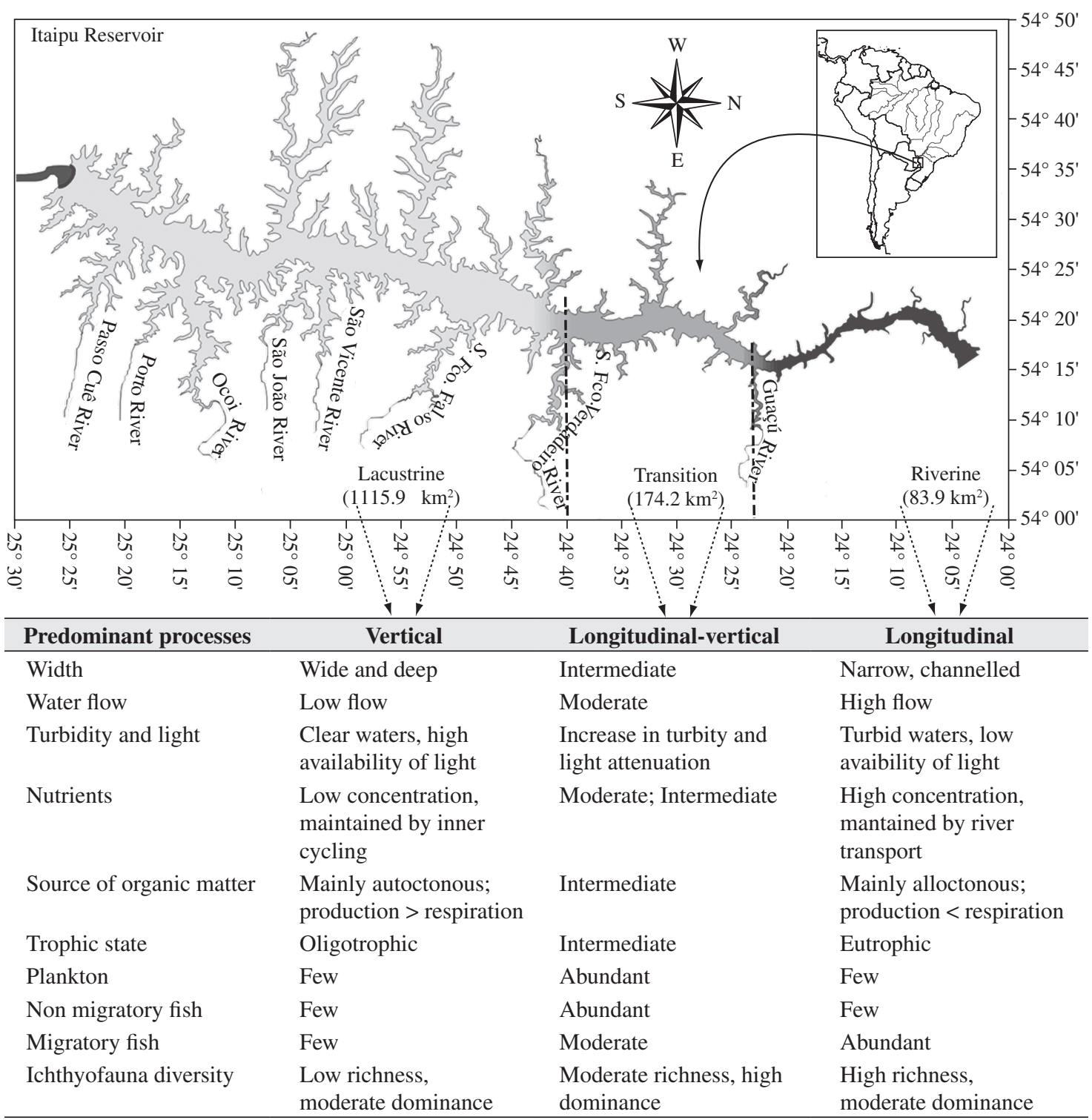

Figure 2. Longitudinal zoning of the Itaipu Reservoir, upper Paraná River basin, indicating limnological and biological factors that characterize each zone (Source: Kimmel et al., 1990; Agostinho et al., 2007b).

implications for fish distribution, as fish search for adequate environments nearby, such as lotic tributaries, free-flowing stretches upstream, or even littoral areas (Agostinho et al., 2007b). During this initial phase, some conditions, such as the release of surface water through dams or the complete mixture of the water column, may swiftly deteriorate environmental quality and cause fish kills. However, the occurrence of stratification, environmental stress and fish kills is a complex phenomenon that depends on several factors such as reservoir depth, basin morphometrics, flooded biomass, residence time, currents and dam filling and operation.

After the initial period of high productivity and environmental instability, the fish community begins to settle into the new ecosystem. Colonization success will depend largely on the existence of species pre-adapted to thrive in environments created by the impoundment (Fernando and Holcik, 1982), such as flooded trunks and logs, macrophyte beds and extensive pelagic areas. Non-migratory (sedentary) species tend to successfully colonize inner zones of reservoirs because they usually have simpler demands with regard to life-cycle dynamics (Agostinho et al., 1999; Figure 2). However, populations of migratory species may experience declines in the reservoir area due to the lentic environment, spatial fragmentation imposed by the dam and the loss of critical habitats needed to complete their life cycles (Agostinho et al., 1999; Ceregato and Petrere Jr, 2003). As result, mi- 
gratory fish concentrate in tributaries or in free-flowing stretches located upstream from reservoirs (Agostinho et al., 2003; Agostinho et al., 2007c).

Spatially, fish assemblages usually distribute along longitudinal and traversal gradients of a reservoir. In terms of richness, fish species tend to remain in environments that preserve the original fluvial characteristics or in those with great habitat heterogeneity, i.e., tributaries and lotic stretches upstream (Agostinho et al., 2007b). The severe modifications that occur in the lacustrine zone alter the amount and quality of original habitat, imposing a severe environmental filter. For instance, migratory or rheophilic species are rarely found in this zone (Agostinho et al., 2003), and it is common to find a gradient of decreasing fish diversity toward dams (Figure 3). As a consequence, the upper third of a reservoir - which includes the free-flowing stretch - usually contains all species of the area; this pattern is well characterized in reservoirs of the upper Paraná River basin (Agostinho et al., 1994; Agostinho et al., 1997). Regarding fish abundance or biomass, the transition zone stands out because of its high primary productivity (Kimmel et al., 1990). These tendencies in species richness and abundance may strengthen with reservoir aging (Figure 3), when small and medium sized species dominate fish assemblages and population increases often occur.

The unequal distribution of fish assemblages along traversal gradients is also a recurrent pattern (Figure 3 ).
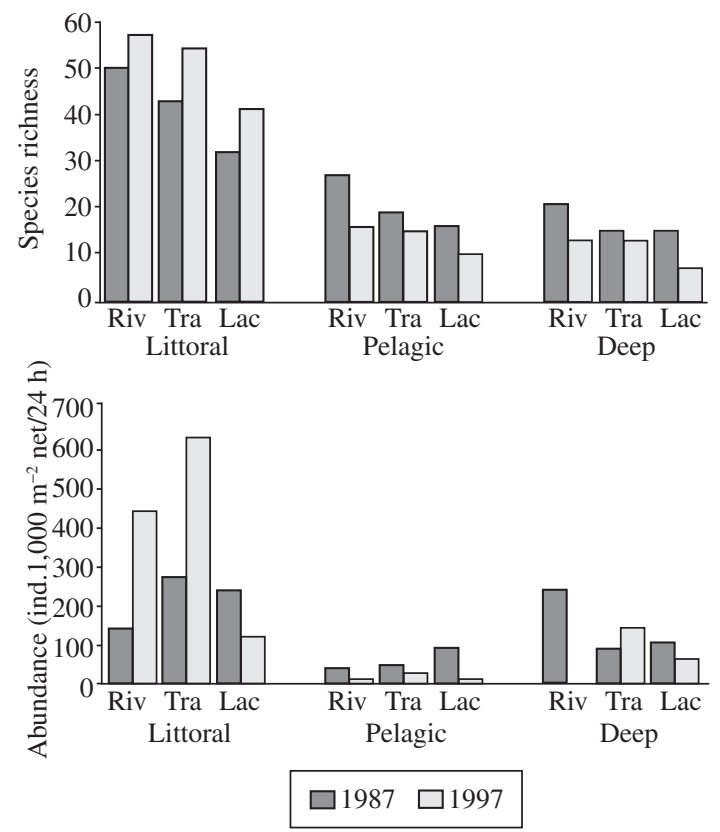

Figure 3. Species richness and abundance in longitudinal $(\mathrm{Riv}=$ riverine; $\operatorname{Tra}=$ transition; $\mathrm{Lac}=$ lacustrine $)$ and traversal (littoral, pelagic and deep) gradients of the Itaipu Reservoir, in 1987 and 1997 (modified from Agostinho et al., 1999).
In all three zones, fish assemblages occupy essentially the littoral environment as a result of the greater availability and heterogeneity of feeding resources, shelter and habitats (Casatti et al., 2003; Smith et al., 2003; Pelicice et al., 2005) and because of unfavorable conditions found in pelagic and deep environments (Agostinho et al., 2007b). Species that successfully colonize littoral areas are sedentary, have the flexibility and tolerance to endure environmental variation, and tend to be generalists in resource usage. Such species are less dependent on the rheophilic behavior and may complete the entire life cycle within the impounded area, e.g., cichlid species, smallsized characins and catfishes. However, the occupation of pelagic areas demands several morphological and behavioral adaptations to allow food intake, reproduction and locomotion. With the exception of some planktivores (e.g., mapará Hypophthalmus edentatus) (Spix,1829), South American species lack such adaptations (Gomes and Miranda, 2001) - a result of their evolutionary history in fluvial ecosystems (there are few natural lakes). As a consequence, few species colonize the vast pelagic areas in reservoirs. The deep layers exhibit similar qualities, particularly in the lacustrine zone. Few species are adapted to persist in such an environment, which eventually becomes inhospitable (Agostinho et al., 2007b). Exceptions are some catfishes, along with the non-native corvina Plagioscion squamosissimus (Hechel, 1840); these are eventually captured in the deep strata of reservoirs in the Paraná River basin. In sum, such uneven distribution results in low fish density and richness in pelagic and deep areas (Figure 3), even though these areas represent the most common habitats in reservoirs (in relation to physical space).

In a temporal perspective, community dynamics are influenced greatly by changes in reservoir primary productivity (Petrere Jr., 1996; Agostinho et al., 1999). After most of the flooded labile biomass (trophic upsurge period or heterotrophic phase) has decomposed, which results in high fish biomass and abundance during the first years (Figure 4), it is common for a reservoir to progress

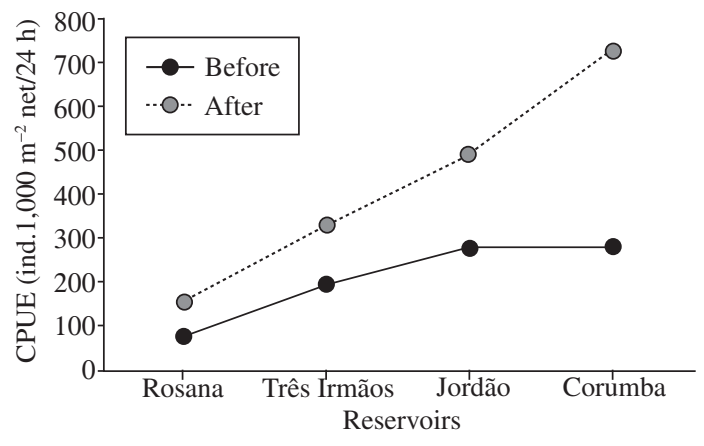

Figure 4. Catch per unit effort (CPUE; ind.1,000 $\mathrm{m}^{-2}$ net/24h) before and during the first years for 4 reservoirs in the Paraná River basin (modified from Agostinho et al., 1999). 
into a phase of trophic depletion and low productivity. The progressive consumption, transport and processing of nutrients/matter, including their retention in the sediment, are common causes of such depletions. Temporal declines in fish abundance were reported in several reservoirs of the Iguaçu, Paranapanema, Tietê and Paranaíba rivers, which, at present, show low primary productivity and fish yields (Gomes et al., 2002; Barrella and Petrere Jr., 2003; Agostinho et al., 2007b). In the Itaipu Reservoir, especially in the lacustrine zone (Figure 5), fish abundance and biomass experienced a pronounced reduction during the first 15 years of the impoundment (Agostinho et al., 1999). Trophic depletion may be reversed in some circumstances, such as i) manipulations of water level, mainly after a prolonged period of low and constant levels, or ii) significant inputs of nutrients through domestic, industrial and agricultural effluents.

Reductions in species richness and fish diversity are also expected after the heterotrophic phase, mainly in the lacustrine zone, as some species are locally eliminated and others become dominant and numerous. Agostinho et al. (2007b), in analyzing fish richness in 75 Brazilian reservoirs, observed that reservoirs tend to have 30 species on average, which is a low number when compared to the high diversity found in typical South American systems (Lowe-McConnel, 1999). In addition, older reservoirs (>20 years) have lower richness when compared to recent reservoirs, harboring approximately 20 species per reservoir. In different basins in France, Irz et al. (2006) concluded that community structure in reservoirs had similarities to structures observed in lakes and natural rivers, but with a predominance of lacustrine species. In South America, because species with pre-adaptations for thriving in pelagic environments are rare, fish species in reservoirs are essentially those that formerly occupied the fluvial system - a feature that hinders the colonization of great reservoirs to some degree.

An aspect of great ecological implication, which has seriously damaged fishing systems in the Paraná River basin, is the strong environmental filter imposed by reservoirs on preexisting reproductive guilds. Several species fail to breed, and population recruitment is af-

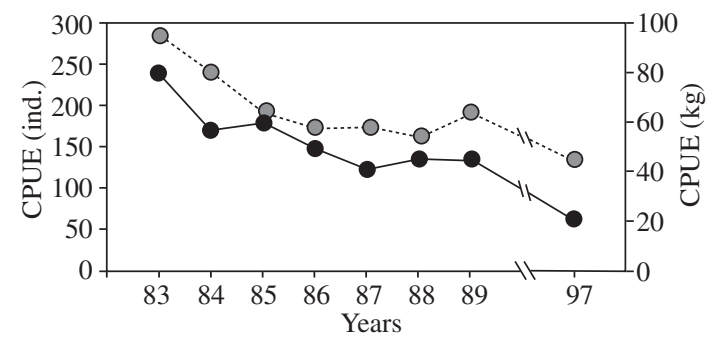

Figure 5. Catch per unit effort (CPUE; ind. and kg.1,000 m ${ }^{-2}$ of net/24h) in the lacustrine zone of the Itaipu Reservoir, documented by experimental fishing during the 15 years after reservoir formation (modified from Agostinho et al., 1999). fected in areas influenced by reservoirs, mainly due to the conservative nature of the reproductive behavior. In this case, species usually require particular habitats and several environmental cues (e.g., temperature, turbidity, hydrological regime) to complete different reproductive stages (e.g., gonad development, migration, spawning, rearing of young). These conditions are present in pristine fluvial areas, but they are deeply modified when the river is impounded.

The decline of long-distance migratory species is the most pronounced consequence of such a filter. The migratory guild undergoes seasonal migrations (piracema) toward spawning habitats located upstream and, consequently, requires free-flowing river stretches. Therefore, recruitment success depends on the presence of and accessibility to spawning areas (upstream stretches in the main channel and tributaries) and nursery habitats (flooded areas downstream) (Agostinho et al., 1993; Gomes and Agostinho, 1997; Agostinho et al., 2004c). Blocked migratory routes, the loss of natural nurseries upstream of dams and the modification of the hydrological regime downstream of dams, in addition to the rheophilic behavior of this guild, are factors directly linked to failures in recruitment and the limited distribution of adults in reservoirs. In addition, rivers that have several reservoirs may trap populations within segments with inadequate conditions for development, feeding and recruitment, thus promoting local extinctions. This phenomenon was well characterized in the Tietê, Grande and Paranapanema - rivers that have cascades of reservoirs where populations of migratory species have declined in recent decades. It is worth noting that migratory species were historically targeted by commercial and artisanal fisheries, but at present, they have disappeared from fishery landings (Agostinho et al., 2007b). Therefore, the migratory guild, which includes large species such as the dourado Salminus brasiliensis (Cuvier, 1816), the pintado Pseudoplatystoma corruscans (Spix and Agassiz, 1829), the pacu Piaractus mesopotamicus (Holmberg, 1887) and the giant jaú Zugaro jahu (Ihering, 1898), is the first group to decline or disappear from impounded areas (Figure 6). Agostinho et al. (2007b), in analyzing 75 Brazilian reservoirs, observed that only $5 \%$ had more than three migratory species amongst the most abundant fish. In addition, more than $50 \%$ of reservoirs lacked migratory species.

It is expected that species with simpler biological demands or greater reproductive plasticity succeed in colonizing the new ecosystem, mainly in lacustrine and transition zones. This is the case for small characins, which lay eggs of small diameter and quick development. In addition, species with internal fecundation (e.g., Auchenipteridae) the young of which usually present low dependence on external conditions for their development, can flourish in newly filled reservoirs (Agostinho et al., 1994). In addition, in recent reservoirs or when oscillations in water level are frequent, species that build nests, lay large adhesive eggs, or develop some degree 

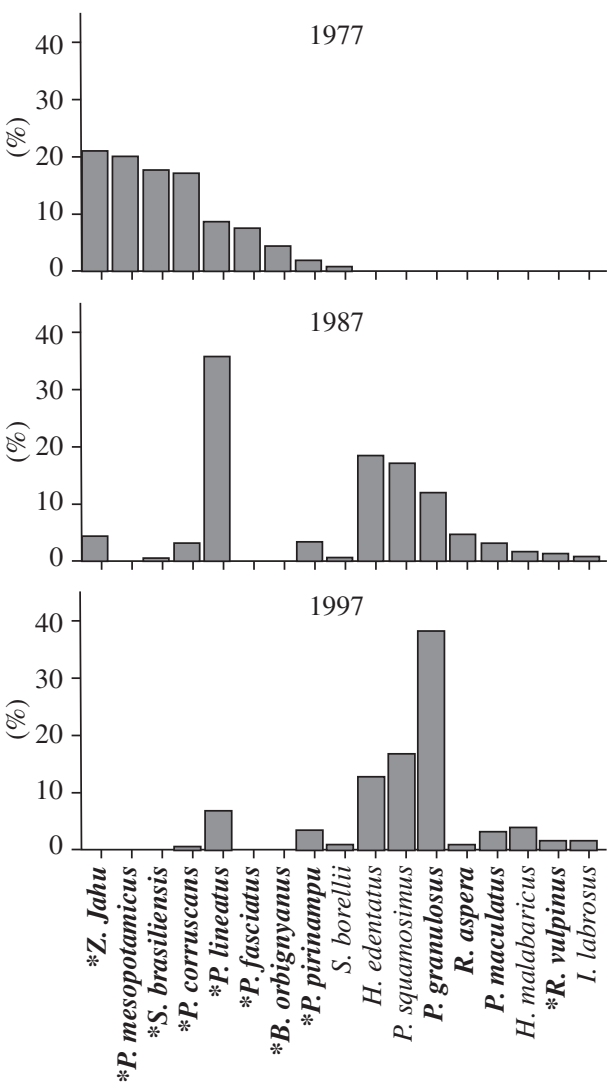

Figure 6. Fishery landings in the area influenced by the Itaipu Reservoir, before (1977) and after damming (1987 and 1997). Species in bold are those considered long-distance migrators, and the sign $(*)$ indicates those that grow above $60 \mathrm{~cm}$ (Source: Agostinho et al., 2003).

of parental care, may have impediments in recruiting young, basically due to the deterioration of water quality, high predation pressure and non-seasonal alterations in water level. In this case, aquatic macrophytes may promote positive effects on fish recruitment by providing shelter, spawning grounds and feeding sites for small species (Casatti et al., 2003; Pelicice et al., 2005). Species that do not undertake long migrations but show rheophilic behavior (preference for running waters) usually seek lotic stretches and tributaries for living and reproducing (Hoffmann et al., 2005; Agostinho et al., 2007b). It is important to emphasize that most species, including many sedentary species, show some degree of dependence on fluvial upstream stretches to complete reproduction; this reality stresses the importance of these areas for the maintenance of fish diversity in reservoirs (Agostinho et al., 2004c).

In short, several studies have shown significant changes in fish communities after the construction of dams, mainly after some degree of stabilization in environmental conditions. In reservoirs located in the upper Paraná River basin, the fish fauna is composed essentially of sedentary species that are generalists in their biological demands, such as cichlids, small characins and catfishes, in addition to some native and nonnative predators, e.g., the piranha (Serrassalmus spp.), traíra (Hoplias spp.), tucunaré (Cichla spp.) and corvina (Plagioscion squamosissimus) (Castro and Arcifa, 1987; Agostinho et al., 1995; Araújo-Lima et al., 1995; Luiz et al., 2005; Agostinho et al., 2007b). These fish successfully colonize littoral habitats, whereas pelagic and deep habitats - which stand out in volume and breadth - remain virtually uninhabited. The decline of long-distance migratory populations is the most apparent event, and it symbolizes the loss of an important service provided by the fluvial ecosystem, with direct implications on fisheries. Because fishing activity must adapt to the new reality, severe alterations in yield, composition and fishing tactics are expected (Petrere Jr., 1996; Agostinho et al., 2005; Okada et al., 2005).

\subsection{Impacts downstream from the dam}

Although investigated less, downstream impacts are equally or even more damaging to the fish fauna, given that impoundments affect primarily water flow dynamics, i.e., the main force working in fluvial ecosystems. Impoundments redistribute river discharge in space and time, affecting several hydrological attributes (e.g., flood period, intensity, amplitude, duration, frequency) and, consequently, the structure, dynamics and functioning of ecosystems located downstream. In addition to flow regulation, other important alterations inevitably follow dam construction, such as blockage of migration routes for some fish species and the retention of sediments and nutrients upstream - a process that decreases turbidity as well as nutrient load and suspended material. This last phenomenon imposes limitations on biological productivity in areas downstream, reducing the fertility of wetlands, and affecting their carrying capacity. The loss of fertilizing services of the flood pulse has been documented in several systems worldwide (WCD, 2000).

When wetlands or floodplains make up the landscape downstream, negative effects of flow regulation are still more pronounced. The structure and functioning of such ecosystems rely on alternate events of flood and drought (Junk et al., 1989; Neiff, 1990; Thomaz et al., 2007), which is a dynamic that disappears with impoundment, because dams usually decrease maximum discharges (absence of seasonal flood pulses) and increase minimum discharges (limiting drought periods). Consequently, hydrological connectivity among environments is considerably modified in space and time. The redistribution of the flooding regime has several direct and indirect effects on fish populations. The decrease in connectivity between the river and lateral plain affects riparian communities and reshapes other environments and interface zones that provide important habitats for fish (Junk et al., 1989; Agostinho and Zalewski, 1995). Alterations in riparian vegetation are expected (WCD, 2000) because plants are adapted to periodic alterna- 
tions of floods and droughts (variation in groundwater level) and cannot thrive in soils with either permanent wet or dry conditions. The fish fauna is also affected by the reorganization of macrophyte beds and by the substitution of plant life-strategies (Thomaz and Bini, 2003). Inaccessibility of lateral lagoons, channels and other seasonally isolated environments also harm the recruitment and maintenance of several fish species, which depend on particular conditions provided by such habitats (Agostinho et al., 2001; Agostinho et al., 2004a). In addition, the prolonged absence of floods might trap fish communities in marginal environments; these may then develop stressful conditions or even dry out.

Studies in the upper Paraná River floodplain, a $230 \mathrm{~km}$ remnant stretch located between Porto Primavera Dam (upstream) and the Itaipu Reservoir (downstream), indicate the significance of impacts caused by flow control. The area had already been impacted by the cascade of reservoirs located upstream, particularly in terms of nutrient retention (Agostinho et al., 1995; Barbosa et al., 1999). The closure of Porto Primavera Dam (1998), however, seriously affected river discharge and impacted recruitment and the maintenance of fish populations in the floodplain (Agostinho et al., 2004b; Agostinho et al., 2005). In this case, reductions in frequency and intensity of seasonal pulses interfered as much in the environmental cues used by fish species to trigger gonad maturation, migration and spawning, in addition to access to critical habitats used by young fish (Agostinho et al., 2004c).

Impacts caused by the Porto Primavera Dam occurred because fish reproductive dynamics and recruitment were closely related to the flood regime (Agostinho et al., 1994; Vazzoler, 1996; Gomes and Agostinho, 1997; Agostinho et al., 2004c). Although flooding events differently affect each reproductive strategy (sedentary, short and long-distance migratory species), the young of all strategies are more abundant in years of intense floods (Agostinho et al., 2001). In addition, flood duration is the main determinant of recruitment intensity, mainly for migratory species (Gomes and Agostinho, 1997; Agostinho et al., 2004c). In this case, high waters enhance connectivity between rivers and lateral environments (e.g., lagoons and isolated channels), where conditions for growth are appropriate (Agostinho et al., 2003). In the absence of floods, even if adults successfully reproduce in tributaries, eggs, larvae and young fish drifting downstream have limited access to lateral habitats, and population recruitment for the following years is negatively affected. In dry years, for instance, when the seasonal flood does not occur as a result of water retention by reservoirs upstream, young migratory fish are not captured in lateral floodplain lagoons (Agostinho et al., 2004c).

Downstream segments are also subjected to other impacts. The operation of hydroelectric impoundments tends to follow demands for electricity, creating variable flow regimes. Such irregular discharge intensifies erosive processes downstream (Souza-Filho et al., 2004) and can eventually dry out the river bed. The intake of poor-quality water by turbines and spillways also creates inhospitable conditions by suddenly altering thermal/gas conditions. Such a phenomenon is more frequent during the heterotrophic phase or when deep layers of the water column are mixed. Finally, fish are subjected to several injuries when they pass across dam structures or when they are surprised by the operation of spillways and turbines (Agostinho et al., 2007b). In any case, extensive fish kills may occur.

\section{Management Actions Taken to Mitigate Impacts}

Management actions to mitigate impacts on biodiversity are rare in Brazil and have not been evaluated or monitored (Agostinho et al., 2004d). Until the 1950s, the main purpose of Brazilian management programs was to ensure the movement of migratory fish through dams by constructing fish ladders, mostly in low order rivers. These programs attempted to counteract the barrier effects of the dam on free fish movements among habitats within population home ranges, thus promoting conservation of migratory fish. These passages did not work properly due to several design flaws, and in the following decades, management focus shifted to promote increased fishery yield by stocking alien or native species, along with fishery controls. Therefore, during this period, the management emphasis was on harvest, and goals related to mitigation of impoundment impacts on fish fauna diversity were abandoned or became secondary. In the 1990s, fish passage construction was reconsidered, and native species were the priorities in stocking programs. An overview of one century of management activity shows that the failures can be attributed to reductionist approaches, inadequate protocols, unclear objectives, absent or inadequate monitoring, and shortcomings because decisions were made based on common sense.

\subsection{Fish passages}

These facilities were the first action related to fishery management taken in the Paraná River basin. This was an attempt to lessen the impact of dams on the upstream migration of fish (usually large species). The first fish pass constructed in Brazil was the Igarapava fish ladder, in Pardo River, built in 1911. More than a dozen fish ladders were constructed in other small rivers before the 1960s (Quiroz, 1988). Currently, dozens of them are operating in many rivers, in addition to fish lifts (Porto Primavera and Funil dams) and bypass channels (Itaipu dam). After the construction of these structures, evaluation was rarely conducted until recent decades. Even now, most of the existing studies are restricted to the efficiency of the ladder allowing fish to go upstream, and their effectiveness for fish conservation has not been evaluated (Agostinho and Gomes, 1997; Agostinho et al., 2002; 2007b). 
An important review of fish passage studies in the Neotropical region was the Proceedings of the International Symposium on Fish Passages in South America, which occurred in 2007 (Lavras-MG) and was published as a special issue of the journal Neotropical Ichthyology. Information in this document clarified some relevant weaknesses in fish conservation, such as high selectivity and favoring the promotion of few species and not always the target ones (Agostinho et al., 2007d; Hahn et al., 2007; Makrakis et al., 2007; Oldani et al., 2007; Fernandez et al., 2007). It was also clear the difficulties in descending migration, passage through dams and the unlikely downstream drift of offspring along a reservoir body, which ultimately will reduce recruitment below dams (Agostinho et al., 2007d; Lopes et al., 2007).

Despite this effort, there is no doubt that large migratory fish can ascend fish ladders and others passages, depending on the adequacy of the design. The capacity of a fish to continue upstream migration (caught downstream of the dam and released inside the reservoir) once relocated to the reservoir is also beyond doubt, as suggested by Agostinho et al. (1993) and Antonio et al. (2007). The main restriction is related to the descending movements of eggs, larvae and adults through the reservoir toward downstream stretches. Yet another common difficulty is the installation of ladders in areas that do not warrant such action; this occurs when spawning grounds or other critical habitats are absent from upstream stretches. This problem often occurs when the construction of ladders is mandated by law in some Brazilian states. Because of these negative aspects, Pelicice and Agostinho (2008) suggested that some fish ladders in the Upper Paraná River basin operate as ecological traps, attracting fish (through water flow) from river stretches where fitness is higher and delivering individuals to environments with poor conditions for recruitment (e.g., a reservoir).

Lessons related to fish passages have not yet been learned. The construction of fish ladders, in general, does not consider the technical characteristics of the dam (type, slope, water discharge, position in relation to the dam) or the nature of the ichthyofauna. This approach increases the risk of failure. Despite scarce and incomplete knowledge, the results indicate that the Brazilian experience of fish passages, based on the North American models for salmonids, has not been profitable. Money and effort, as well as opportunities to plan and conduct ecological studies, were wasted. In addition to problems and failures reported, it is possible that the incorrect use of fish passages is causing additional impacts on some fish populations, making conservation much more challenging (Pelicice and Agostinho, 2008).

\subsection{Stocking}

Stocking was another tool intensively used in recent decades with native and non-native species, especially in reservoirs. It was taken as an alternative for fish ladders, but it was considered expensive and inefficient. Alternative actions based on actual data of the exploited resources and environments were neglected with the allegation that reservoir fish production could not wait for the slow pace of scientific research.

This led to the construction of several hatcheries, which cost an enormous amount of money. It was hoped that the widespread hatcheries and subsequent stocking would improve the reservoir fishery. Technical difficulties in producing fry of native species led managers to initially opt for non-native species. As many as twenty species were introduced from 1970-1990 in south and southeastern Brazilian reservoirs (Agostinho et al., 2000). Although non-natives species are still stocked, this trend has decreased in recent years (Agostinho et al., 2007b).

Many attempts to promote a self-sustaining population from stocking were unsuccessful. Only species introduced from the Amazon River basin, such as Plagioscion squamosissimus, Cichla kelberi Kullander and Ferreira, 2006 (=C. monoculus), both piscivores, were successful. Oreochromis niloticus (Linnaeus, 1758) is abundant in reservoirs of the Grande River and in upstream impoundments of the Tietê River (Agostinho et al., 2007b). Plagioscion squamosissimus is the most abundant predator in large reservoirs of the basin, whereas successful colonization by $C$. kelberi depends on the presence of vast littoral zones and water level stability (Agostinho et al., 1999) because this species uses shallow and nearshore areas for spawning, where they practice parental care (Williams et al., 1998). However, the evaluation of their impacts on biodiversity and on other fishing stocks are recent (Santos et al., 1994; Gomiero and Braga, 2004; Pelicice and Agostinho (in press). The growing pressure from environmental agencies and the numerous failures of stocking programs using exotic species, which is easily detected by the absence of target fish in the environment, led the hydropower companies to breed and to stock native species. This trend began after the 1980s and continues now. However, the evaluation of the stocking efficiency is not properly performed, and possible impacts related to poor genetic quality of the parental fish has not been examined (Toledo Filho et al., 1992; Agostinho et al., 2007a; 2007b).

According to data on yield from artisanal fisheries and stocking effort (number of fry released) in six reservoirs operated by the Electricity Company of São Paulo State (Torloni et al., 1993; CESP, 1996), there is no relationship between these variables. In spite of these results, stocking is still the main management strategy used by hydropower companies and environmental agencies as well as the main strategy requested by stakeholders. The influence of politicians must be considered in most of these stocking programs, as stated by De Silva (1987), who observed that stocking in Thailand is done more for political reasons than for fishery enhancement because fisheries rely on endemic species (returns of the stocked fish are very low). Agostinho et al. (2005) also suggested similar circumstances related to the conservation of aquatic fauna in Brazil's inland waters. 
The failures of stocking programs can be attributed not only to the shortage of information but also to the negligence of utilizing the existing data. In general, stocking decisions were made without considering the status of wild stocks, environmental restrictions or requirements of target species. There was uncertainty in species selection, adequate size, habitat and season for stocking. Recent results obtained in the Jupiá and Três Irmãos reservoirs, with better genetic control in the hatchery and stocking fish of larger size $(>10 \mathrm{~cm})$ and using naturally depleted native species (Piaractus mesopotamicus), were more successful (CESP, 2000). However, there is no information to evaluate if these stocks reproduce in the reservoirs or whether they will require continuous stocking.

\subsection{Fishery control}

Fisheries are controlled by licensing, equipment and net mesh size restrictions, length limits and season restrictions. Licenses are needed for both artisanal (professional) and sport (recreational) fishers and provided by the Secretaria Especial de Aquicultura e Pesca (a governmental agency). Regulations for the purpose of protecting juveniles, spawning grounds and spawning season have not been efficient. These actions are limited by the lack of information on fish populations, financial resources, and workforce to enforce the legislation. The absence of monitoring and a clear goal about what is the subject of protection are also problems (Agostinho and Gomes, 1997; Agostinho et al., 2007a).

It is also common in some years, when floods are delayed, for the fishing season to reopen just when fish are beginning to migrate or spawn. In tributaries of the upper Paraná River, fisheries are regulated by different legislation. Artisanal fishing with gillnets is not permitted in the states of Goiás, Mato Grosso do Sul and Minas Gerais, and it is regulated in the Paraná and São Paulo states. Different legislation creates difficulties in controlling fisheries at border rivers between these states. Sport fisheries, however, are permitted in all states.

The absence of data on catch and effort, except for specific places (Okada et al., 2005), does not allow the determination of the status of exploited stocks, which are the basis of fishery regulations. Recent participation of universities and research institutes in defining policies is improving this situation (Agostinho et al., 1994; 2007b), but the absence of data will be resolved only with new research programs and monitoring studies. The effectiveness of actions controlling fisheries will depend on the degree of enforcement applied by Federal and State Agencies.

\section{Final Considerations}

Impoundments changed the landscape of the upper Paraná River, fragmenting the watershed and regulating its water flow. This fact is relevant, especially to the preservation of migratory fish populations, which include the largest fish in the basin with the highest fishery appeal (at least 16 species; Agostinho et al., 2003; 2007a). As mentioned before, these species require different compartments of the basin for development. Thus, they usually need a spawning area (upper part of tributaries), nursery (usually lagoons and secondary channels of a floodplain) and feeding areas (tributaries, main channels and reservoirs). The exigency to use different compartments of the system for different life stages makes protection actions complex and demands initiatives that interfere with the structure of the system as a whole (cyclical variations of water level, artificial flooding of marginal lagoons). Taking into account this reality, the preservation of the remnant floodplain is essential not only for the maintenance of fish diversity but also for the production level of fishery stocks (service provided by the ecosystem; Gomes and Agostinho, 1997; Gomes and Miranda, 2001; Agostinho et al., 2004b).

Ideally, management should take an ecosystem approach (Likens, 1992; Beverton, 1998; Pauly, 1998), including the preservation of water quality, food webs, biotic and abiotic interactions and population and community structure; e.g., pristine ecosystem dynamics. However, present knowledge of the responses of aquatic resources to river damming, fishery exploitation and other impacts is still quite poor. The situation is more uncertain if we consider other components of the ecosystem. Thus, to promote the conservation of biodiversity and sustainable exploitation, it is necessary to establish an adequate knowledge base on aquatic resources through biodiversity surveys, including species distributions and requirements, ecological processes, functioning of ecosystems and implementation of a database that is accessible to researchers and decision makers.

Equally, it is necessary to understand the pattern of fish markets (for consumption), social perceptions and economic constraints. Managers need to be flexible and to foresee the possibility of interrupting fisheries or taking management actions when necessary. Fishery legislation and control needs empirical information and clarity on this objective, efficient social communication, and the involvement of fisher organizations in decision-making. Also, it may be made clear that fisheries are good indicators of environmental change and that fishers play an important role in resources conservation when they are organized. Finally, communication needs to improve among scientists, managers, fishers and other stakeholders. Other users of the water, such as power generation (hydrological regulation) and aquaculture need rationalization and to consider fisheries and conservation interests together.

Traditionally, monitoring in the Paraná River basin as well as in Brazil does not follow management actions. This explains why some management actions took so much time to be abandoned or corrected (i.e., stocking, fish passages). Monitoring, in addition to evaluating the courses of action, permits an improvement in knowledge about the system and promotes modifications in manage- 
ment programs. At present, the Environmental Impact Report, a legal requirement, usually recommends monitoring and research programs because a lack of information does not allow for good evaluation of impacts. In addition, more integration among monitoring, management and research is necessary. For example, research indicates that young target species fish grow in marginal lagoons, but results from fisheries monitoring reveal no increases in fish stocks over several years. Stocking programs continue to add (incorrectly) fry of these same species into the river channels or the main body of reservoirs. Monitoring and management may indicate what options should be investigated, and research results may improve monitoring or management methods.

In conclusion, impoundments have reshaped the upper Paraná River basin in structural and functional terms. Consequently, the conservation of fish diversity will demand much political, societal and scientific effort to succeed. Fishery/biodiversity management programs must incorporate a wide perspective of the system (environment, fishers and fish) and foresee a permanent ecosystem evaluation through monitoring and specific studies, whose results would be used to improve the system. In addition, the hydrographic dimensions and multiples uses of the basin deserve attention, but considering biological, political and socio-economic constraints.

Acknowledgements - We thank Jaime L. L. Pereira for drawing the figures, the Núcleo de Pesquisas em Limnologia, Ictiologia e Aquicultura from the Universidade Estadual de Maringá for supplying the infra-structure. CNPq provided grants for researchers and CNPq/PELD and UNESCO financial support.

\section{References}

AGOSTINHO, AA., VAZZOLER, AEAM., GOMES, LC. and OKADA, EK., 1993. Estratificación espacial y comportamiento de Prochilodus scrofa en distintas fases del ciclo de vida, en la planicie de inundación del alto río Paraná y embalse de Itaipu, Paraná, Brazil. Rev. Hydrobiol. Trop., vol. 26, no.1, p. 79-90.

AGOSTINHO, AA., JÚLIO Jr, HF. and PETRERE Jr, M., 1994. Itaipu reservoir (Brazil): impacts of the impoundment on the fish fauna and fisheries. In COWX, IG. (Ed.). Rehabilitation of freshwater fisheries. Osney Mead: Fishing News Books. p. 171-184.

AGOSTINHO, AA., VAZZOLER, AEAM. and THOMAZ, SM., 1995. The High River Paraná basin: limnological and ichthyological aspects. In TUNDISI, JG., BICUDO, CEM. and MATSUMURA-TUNDISI, T. (Eds.). Limnology in Brazil. Rio de Janeiro: ABC/SBL. p. 59-103.

AGOSTINHO, AA. and ZALEWSKI, M., 1995. The dependence of fish community structure and dynamics on floodplain and riparian ecotone zone in Paraná River, Brazil. Hydrobiologia, vol. 303 , no.1-3, p. 141-148.

AGOSTINHO, AA., FERRETTI, CML., GOMES, LC., HAHN, NS., SUZUKI, HI., FUGI, R. and ABUJANRA, F., 1997. Ictiofauna de dois reservatórios do rio Iguaçu em diferentes fases de colonização: Segredo e Foz do Areia. In AGOSTINHO, AA. and GOMES, LC. (Eds.). Reservatório de Segredo: bases ecológicas para o manejo. Maringá: EDUEM. p. 275-292.
AGOSTINHO, AA., MIRANDA, LE., BINI, LM., GOMES, LC., THOMAZ, SM. and SUZUKI, HI., 1999. Patterns of colonization in neotropical reservoirs, and prognoses on aging. In TUNDISI, JG. and STRASKRABA, M. (Eds.). Theoretical reservoir ecology and its applications. Leiden: Backhuys Publishers. p. 227-265.

AGOSTINHO, AA., JULIO Jr., HF. and TORLONI, CE., 2000. Impactos causados pela introdução e transferência de espécies aquáticas: uma síntese. In Anais VIII Simpósio Brasileiro de Aqüicultura. Piracicaba, SP: ABRAQ. p. 59-75

AGOSTINHO, AA., GOMES, LC. and ZALEWSKI, M., 2001. The importance of floodplains for the dynamics of fish communities of the Upper River Paraná. Ecohydrol. Hydrobiol., vol. 1, no. 1-2, p. 209-217.

AGOSTINHO, AA., GOMES, LC., SUZUKI, HI. and JÚLIO Jr, HF., 2003. Migratory fishes of the Upper Paraná River Basin, Brazil. In CAROLSFELD, J., HARVEY, B., ROSS, C. and BAER, A. (Eds.). Migratory fishes of South America: biology, fisheries and conservation status. Ottawa: World Fisheries Trust, International Bank for Reconstruction and Development/The World Bank. p. 19-98.

AgOstinho, AA., BINI, LM., GOMES, LC., JÚLIO Jr, HF., PAVANELLI, CS. and AGOSTINHO, CS., 2004a. Fish assemblages. In THOMAZ, SM., AGOSTINHO, AA. and HAHN, NS. (Eds.). The Upper Paraná River and its floodplain: physical aspects, ecology and conservation. Leiden: Backhuys Publishers. p. 223-246.

AGOSTINHO, AA., THOMAZ, SM. and GOMES, LC., 2004b. Threats for biodiversity in the floodplain of the Upper Paraná River: effects of hydrological regulation by dams. Ecohydrol. Hydrobiol., vol. 4, no. 3, p. 267-280.

AGOSTINHO, AA., GOMES, LC., VERÍSSIMO, S. and OKADA, EK., 2004c. Flood regime, dam regulation and fish in the Upper Paraná River: effects on assemblage attributes, reproduction and recruitment. Rev. Fish Biol. Fisheries., vol. 14, no. 1, p. 11-19.

AGOSTINHO, AA., GOMES, LC., LATINI, JD., 2004d. Fisheries management in brazilian reservoirs: lessons from/for South América. Interciencia, vol. 29, no. 6, p. 334-338.

AGOSTINHO, AA., THOMAZ, SM. and GOMES, LC., 2005. Conservation of the biodiversity of Brazil's inland waters. Conserv. Biol., vol. 19, no.3, p. 646-652.

AGOSTINHO, AA., PELICICE, FM., PETRY, AC., GOMES, LC. and JÚLIO Jr, HF. 2007a. Fish diversity in the upper Paraná River basin: habitats, fisheries, management and conservation. $J$. Aquat. Ecosyst. Health. Manag., vol. 10, no. 2, p. 174-186.

AGOSTINHO, AA., GOMES, LC. and PELICICE FM., 2007b. Ecologia e manejo de recursos pesqueiros em reservatórios do Brasil. Maringá: Eduem. 501 p.

AgOstinho, AA., MARQUES, EE., AGOSTINHO, CS., ALMEIDA, DA., OLIVEIRA, RJ. and RODRIGUES, JBM., 2007c. Fish ladder: migration on one way routes? Neotropical Ichthyology, vol. 5, no. 2, p. 121-130.

AGOSTINHO, CS., AGOSTINHO, AA., PELICICE, FM., ALMEIDA, DA. and MARQUES, EE., 2007d. Selectivity of fish ladders: the first bottleneck in fish movement. Neotropical Ichthyology, vol. 5, no. 2, p. 205-213.

ALVES, CBM., GODINHO, AL., GODINHO, HP. and TORQUATO, VCA., 1998. Ictiofauna da represa de Itutinga, Rio Grande (Minas Gerais - Brasil). Rev. Bras. Biol. = Braz. J. Biol., vol. 58, no. 1, p. 121-129. 
ANTONIO, RR., AGOSTINHO, AA., PELICICE, FM., BAILLY, D., OKADA, EK. and DIAS, JHP., 2007. Blockage of migration routes by dam construction: can migratory fish find alternative routes? Neotropical Ichthyology, vol. 5, no. 2, p. 177-184.

ARAUJO, FG. and SANTOS, LN., 2001. Distribuição da associação de peixes no Reservatório de Lajes, RJ. Braz. J. Biol., vol. 61 , no. 4 , p. 563-576.

ARAÚJO-LIMA, CARM., AGOSTINHO, AA. and FABRÉ, NN., 1995. Trophic aspects of fish communities in Brazilian rivers and reservoirs. In TUNDISI, JG., BICUDO, CEM. and MATSUMURA-TUNDISI, T. (Eds.). Limnology in Brazil. São Paulo: ABC/SBL. p. 105-136.

BARBOSA, FAR., PADISÁK, J., ESPÍNDOLA, ELG., BORICS, G. and ROCHA, O., 1999. The cascading reservoir continuum concept (CRCC) and its application to the river Tietê-basin, São Paulo State, Brazil. In: JG. TUNDISI and M. STRASKRABA (eds.). Theoretical reservoir ecology and its applications. Leiden: Backhuys Publishers. p. 425-437.

BARRELLA, W. and PETRERE Jr., M., 2003. Fish community alterations due to pollution and damming in Tietê and Paranapanema rivers (Brazil). River Res. Appl., vol. 19, no. 1, p. 59-76.

BAXTER, RM., 1977. Environmental effects of dams and impoundments. Annu. Rev. Ecol. Syst., vol. 8, p. 255-283.

BEVERTON, R., 1998. Fish, fact and fantasy: a long view. Rev. Fish Biol. Fish, vol.8, no. 3, p. 229-249.

BONETTO, AA., 1986. The Paraná River system. In DAVIES, BR. and WALKER, KF. (Eds.). The ecology of river systems. The Netherlands: Dr. Junk Publisher. p. 541-556.

CASATTI, L., MENDES, HF. and FERREIRA, KM., 2003. Aquatic macrophytes as feeding site for small fishes in the Rosana Reservoir, Paranapanema River, southeastern Brazil. Rev. Bras. Biol. - Braz. J. Biol., vol. 63, no. 2, p. 213-222.

CASTRO, ACL., 1997. Aspectos ecológicos da comunidade ictiofaunística do reservatório de Barra Bonita, SP. Rev. Bras. Biol. $=$ Braz. J. Biol., vol. 57, no. 4, p. 665-676.

CASTRO, RMC. and ARCIFA, MS., 1987. Comunidades de peixes de reservatórios no sul do Brasil. Rev. Bras. Biol. $=$ Braz. J. Biol., vol. 47, no. 4, p. 493-500.

CEREGATO, SA. and PETRERE Jr., M., 2003. Comparação financeira entre as pescarias artesanais no complexo de Urubupungá, no médio rio Paraná (Brasil). Braz. J. Biol., vol. 63, no. 4 , p. $673-682$.

CESP, 1996. Aspectos limnológicos, ictiológicos e pesqueiros de reservatórios da CESP no período de 1986 a 1994. São Paulo: CESP. 79 p.

-, 2000. Programa de manejo pesqueiro: plano de trabalho 20002001. São Paulo: CESP. 74 p.

DE SILVA, SS., 1987. The reservoir fisheries in Asia. In De SILVA, SS. (Ed.). Reservoir fishery management and development in Asia. Canadá: International Development Research Centre. p. 19-28.

FERNANDEZ, DR., AGOSTINHO, AA., BINI, LM. and GOMES, LC., 2007. Environmental factors related to entry into and ascent of fish in the experimental ladder located close to the Itaipu Dam. Neotropical Ichthyology, vol. 5, no. 2, p. 153-160.

FERNANDO, CH. and HOLČÍK, J., 1982. The nature of fish communities: a factor influencing the fishery potential and yields of tropical lakes and reservoirs. Hydrobiologia, vol. 97, no. 2, p. $127-140$.

GOMES, LC. and AGOSTINHO, AA., 1997. Influence of the flooding regime on the nutritional state and juvenile recruitment of the curimba, Prochilodus scrofa, Steindachner, in Upper Paraná River, Brazil. Fish. Manag. Ecol., vol. 4, no. 4, p. 263-274.

GOMES, LC. and MIRANDA, LE., 2001. Riverine characteristics dictate composition of fish assemblages and limit fisheries in reservoirs of the Upper Paraná River Basin. Regul. Rivers: Res. Manag., vol. 17, no. 1, p. 67-76.

GOMES, LC., MIRANDA, LE. and AGOSTINHO, AA., 2002. Fishery yield relative to chlorophyll $a$ in reservoirs of the Upper Paraná River, Brazil. Fish. Res. (AMST), vol. 55, no. 1, p. $335-340$

GOMIERO, LM. and BRAGA, FMS. 2004. Alimentação de espécies introduzidas de Cichla (Perciformes, Cichlidae) no reservatório de Volta Grande, Rio Grande (MG/SP). Braz. J. Biol. = Rev. Bras. Biol., vol. 64, no. 4, p. 787-795.

GRAÇA, WJ. and PAVANELLI, CS., 2007. Peixes da planície de inundação do alto rio Paraná e áreas adjacentes. Maringá: Eduem, $241 \mathrm{p}$.

HAHN, L., ENGLISH, K., CAROSFELD, J., SILVA, LGM., LATINI, JD., AGOSTINHO, AA. and FERNANDEZ, DRF., 2007. Preliminary study on the application of radio-telemetry techniques to evaluate movements of fish in the Lateral Canal at Itaipu Dam, Brazil. Neotrop. Ichthyol., vol. 5, no. 2, p. 103-108.

HOFFMANN, AC., ORSI, ML., SHIBATTA, OA., 2005. Diversidade de peixes do reservatório da UHE Escola Engenharia Mackenzie (Capivara), Rio Paranapanema, bacia do alto rio Paraná, Brasil, e a importância dos grandes tributários na sua manutenção. Iheringia, vol. 95, no. 3, p. 319-325.

IBGE - Instituto Brasileiro de Geografia e Estatística, 1990. Geografia do Brasil. Rio de Janeiro. Região Sul, vol. 2.

IRZ, P., ODION, M., ARGILliER, C. and PONT, D., 2006. Comparison between the fish communities of lakes, reservoirs and rivers: can natural systems help define the ecological potential of reservoirs? Aquat. Sci., vol. 68, no. 1, p. 109-116.

JUNK, WJ., BAYLEY, PB. and SPARKS, RE., 1989. The flood pulse concept in river-floodplain systems. Can. Spec. Publ. Fish. Aquat. Sci., vol. 106, p. 110-127.

KIMMEL, BL., LIND, OT. and PAULSON, LJ., 1990. Reservoir primary production. In: KW. THORNTON, BL. KIMMEL, FE. PAYNE (Eds.). Reservoir limnology: ecological perspectives. New York: J. Wiley \& Sons. p. 133-194.

LANGEANI, F., CASTRO, RMC., OYAKAWA, OT., SHIBATTA, OA., PAVANELLI, CS. and CASATTI, L., 2007. Diversidade da ictiofauna do Alto Rio Paraná: composição atual e perspectives futures. Biota Neotrop., vol. 7, no. 3, p. 181-197.

LÉVÊQUE, C., OBERDORFF, T., PAUGY, D., STIASSNY, MLJ. and TEDESCO, PA., 2008. Global diversity of fish (Pisces) in freshwater. Hydrobiologia, vol. 595, no. 1, p. 545-567.

Likens, GE. 1992. The ecosystem approach: its use and abuse. Series Excellence in Ecology. Oldendorf, Germany: Ecology Institute. $166 \mathrm{p}$

LOPES, CM.,ALMEIDA, FS., ORSI, ML., BRITO, SGC., SIROL, RN. and SODRÉ, LMK., 2007. Fish passage ladders from Canoas Complex - Paranapanema River: evaluation of genetic structure maintenance of Salminus brasiliensis (Teleostei: Characiformes). Neotropical Ichthyology, vol. 5, no. 2, p. 131-138. 
LOWE-MCCONNELL, RH., 1999. Estudos ecológicos de comunidades de peixes tropicais. São Paulo: EDUSP. 534 p.

LUIZ, EA., PETRY, AC., PAVANELLI, CS., JÚLIO Jr, HF., LATINI, JD. and DOMINGUES, VM., 2005. As assembléias de peixes de reservatórios hidrelétricos do Estado do Paraná e bacias limítrofes. In RODRIGUES, L., THOMAZ, SM., AGOSTINHO, AA., GOMES, LC. (Org.). Biocenoses em reservatórios: padrões espaciais e temporais. São Carlos: RiMa. p. 169-184.

MAKRAKIS, S., MAKRAKIS, MC., WAGNER, RL., DIAS, JHP. and GOMES, LC., 2007. Utilization of the fish ladder at the Engenheiro Sergio Motta Dam, Brazil, by long distance migrating potamodromous species. Neotrop. Ichthyol., vol. 5, no. 2, p. 197-204.

MATSUMURA-TUNDISI, T., TUNDISI, JG., SAGGIO, A., OLIVEIRA NETO, AL. and ESPÍNDOLA, EG., 1991. Limnology of Samuel Reservoir (Brazil, Rondônia) in the filling phase. Verh. Int. Verein. Limnol., vol. 24, no. 3, p. 1482-1488.

NEIFF, JJ., 1990. Ideas para la interpretación ecológica del Parana. Interciencia, vol. 15, no. 6, p. 424-441.

NILSSON, C., REIDY, CA., DYNESIUS, M. and REVENGA, C., 2005. Fragmentation and flow regulation of the world's large river systems. Science, vol. 308, no. 5720, p. 405-408.

OKADA, EK., AGOSTINHO, AA. and GOMES, LC., 2005. Spatial and temporal gradients in artisanal fisheries of a large Neotropical reservoir, the Itaipu Reservoir, Brazil. Can. J. Fish. Aquat. Sci., vol. 62, no.3, p. 714-724.

PAULY, D., CHRISTENSEN, V., DALSGAARD, J., FROESE, R. and TORRES Jr., F., 1998. Fishing down marine foodwebs. Science, vol. 279, no. 5352, p. 860-863.

QUIRÓS, R., 1988. Estructuras para asistir a los peces no salmónidos en sus migraciones: América Latina Instituto Nacional de Investigación Y Desarollo Pesquero. Rome; FAO. 50 p.

OLDANI, NO., BAIGUN, CRM., NESTLER, JM. and GOODWIN, RA., 2007. Is fish passage technology saving fish resources in the lower La Plata River basin?. Neotropical Ichthyology, vol. 5, no. 2, p. 89-102.

OLIVEIRA, EF., GOULART, E. and MINTE-VERA, CV., 2004. Fish diversity along spatial gradients in the Itaipu Reservoir, Paraná, Brazil. Braz. J. Biol., vol. 64, no. 3, p. 447-458

PELICICE, FM. and AGOSTINHO, A. A. Fish passage facilities as ecological traps in large Neotropical rivers. Cons. Biol., vol. 22, no. 1 , p. $180-188,2008$.

PELICICE, FM., AGOSTINHO, AA. and THOMAZ, SM., 2005. Fish assemblages associated with Egeria in a tropical reservoir: investigating the effects of plant biomass and diel period. Acta Oecol., vol. 27, no. 1, p. 9-16.

PELICICE, FM. and AGOSTINHO, AA. Fish fauna destruction after the introduction of a non-native predator (Cichla kelberi) in a Neotropical reservoir. Biological Invations. DOI 10.1007/ s10530-008-9358-3 (in press).

PETRERE Jr, M. and AGOSTINHO, AA. 1993. La pesca en el tramo brasileno del rio Paraná. Fao Informe de Pesca, vol. 490, p. $52-72$.

PETRERE Jr, M., 1996. Fisheries in large tropical reservoirs in South America. Lakes Reserv.: Res. Manag., vol. 2, no. 1-2, p. 111-133.

PETTS, GE. 1984. Impounded rivers: perspectives for ecological management. Chichester: J. Wiley \& Sons. 326 p.
POFF, NL., ALLAN, JD., BAIN, MB., KARR, JR., PRESTEGAARD, KL., RICHTER, BD., SPARKS, RE. and STROMBERG, JC., 1997. The natural flow regime. BioScience, vol. 47, no. 11, p. 769-784.

REIS, RE., KULLANDER, SO. and FERRARIS Jr, CJ. (Eds.), 2003. Checklist of the freshwater fishes of South and Central América. Porto Alegre: EDIPUCRS. 729 p.

SANTOS, GB., MAIA-BARBOSA, PM., VIEIRA, F., and LOLEZ, CM., 1994. Fish and zooplankton community structure in reservoirs of southeastern Brazil: Effects of the introduction of exotic predatory fish. In PINTO-COELHO, RM., GIANI, A., and SPERLING, EV. (Eds.). Ecology and Human Impact on Lakes and Reservoirs in Minas Gerais. Belo Horizonte: UFMG. p. 115-132.

SMITH, WS., PEREIRA, CCGF., ESPÍNDOLA, ELG. and ROCHA, O., 2003. A importância da zona litoral para a disponibilidade de recursos alimentares à comunidade de peixes em reservatórios. In HENRY, R. (Org.). Ecótonos nas interfaces dos ecossistemas aquáticos. São Carlos: RiMa. p. 233-248.

SOUZA FILHO, EE., ROCHA, PC., COMUNELLO, E. and STEVAUX, JC., 2004. Effects of the Porto Primavera Dam on physical environment of the downstream floodplain. In THOMAZ, SM., AGOSTINHO, AA. and HAHN, NS. (Eds.). The Upper Paraná River and its floodplain: physical aspects, ecology and conservation. Leiden: Backhuys Publishers. p. 55-74.

THOMAZ, SM., PAGIORO, TA., ROBERTO, MC., PIERINI, SA. and PEREIRA, G., 2001. Padrões de variação espacial e temporal de fatores limnológicos. In Estudos ictiológicos na área de influência do AHE Corumbá: biologia e ecologia de peixes do reservatório de Corumbá: bases para o manejo. Maringá: Universidade Estadual de Maringá, Nupélia/ Furnas. p. 15-38. Relatório Técnico.

THOMAZ, SM. and BINI, LM., 2003. Análise crítica dos estudos sobre macrófitas aquáticas desenvolvidos no Brasil. In THOMAZ SM. and BINI, LM. (Eds.). Ecologia e manejo de macrófitas aquáticas. Maringá: Eduem. p. 19-38

THOMAZ, SM., BINI, LM. and BOZELLI, RL., 2007. Floods increase similarity among aquatic habitats in river-floodplain systems. Hydrobiologia, vol. 579, no. 1, p. 1-13.

TOLEDO FILHO, SA., ALMEIDA, LF., GALHARDO, E. and FORESTI, F., 1991. Monitoramento, manipulação e conservação genética de peixes. In AGOSTINHO, AA. and CECILIO, BE. (Eds.). Situação atual e perspectivas da ictiologia no Brasil. Maringá: Eduem. p. 69-78.

TUNDISI, JG. and MATSUMURA-TUNDISI, T., 2003. Integration of research and management in optimizing multiple uses of reservoirs: the experience of South America and Brazilian cases studies. Hydrobiologia, vol. 500, no. 1-3, p. 231-242.

VAZZOLER, AEAM., 1996. Biologia da reprodução de peixes teleósteos: teoria e prática. São Paulo; Maringá: EDUEM/SBI. $169 \mathrm{p}$.

WCD (WORLD COMMISSION ON DAMS)., 2000. Dams and development: a new framework for decision-making. The report of the World Commission on Dams. London, Sterling: Earthscan Publishing. 404 p.

WILLIAMS, JD., WINEMILLER, KO., TAPHORN, DC. and BALBAS, L., 1998. Ecology and status of piscivores in Guri, an oligotrophic Tropical Reservoir. N. Am. J. Fish. Manag., vol. 18, no. 2 , p. $274-285$. 